\title{
Poder não é querer: preferências restritivas e redesenho institucional no Supremo Tribunal Federal pós-democratização*
}

\author{
Being able to is not wanting to: restrictive \\ preferences and institutional design in the \\ post-democratization Supreme Federal Court
}

Diego Werneck Arguelhes'

Artigo recebido em maio de 2014. Aceito para publicação em maio de 2014.

${ }^{1}$ Diego Werneck Arguelhes é Professor Pesquisador da FGV Direito Rio. Bacharel em Direito e Mestre em Direito Público pela UERJ. Master of Laws (LL.M.) e doutorando (J.S.D.) pela Universidade Yale (EUA). Uma versão anterior deste trabalho foi apresentada no ciclo de seminários "A Jurisdição Constitucional em 2020", na Universidade de Brasília, em 10 de abril de 2012. Agradeço aos participantes do seminário, em especial a Jorge Galvão, pelo produtivo debate. Gostaria de agradecer também a Andres Del Rio, Carlos Alexandre Campos, Daniel Sarmento, Eduardo Jordão, Fabiana Luci de Oliveira, Fábio Shecaira, Feliciano Guimarães, Fernando Leal, Fernando Limongi, Joaquim Falcão, Leandro Molhano Ribeiro, Luís Roberto Barroso, Mariana Pargendler e Mario Machado por comentários a versões anteriores deste trabalho. Várias das ideias aqui apresentadas foram desenvolvidas ao longo dos últimos anos em permanente diálogo com Leandro Molhano Ribeiro. A responsabilidade pelos erros remanescentes é exclusivamente minha.

\section{Resumo}

Em muitas explicações existentes sobre o atual protagonismo do Supremo Tribunal Federal na política nacional, tende-se a enfatizar variáveis e processos que independem da vontade dos Ministros - variáveis como desenho institucional, texto constitucional, expectativas sociais e comportamento estratégico dos atores políticos ao redor do tribunal. Contudo, embora essas variáveis exógenas sejam importantes para explicar o papel que o tribunal vem assumindo, elas são insuficientes para explicar algumas transformações e variações nesse papel dos anos 90 para cá. Neste trabalho, argumenta-se que as preferências dos Ministros do STF sobre como exercer o poder de que dispõem e de quanto poder deveriam dispor podem interagir com as variáveis exógenas para gerar mais ou menos participação do STF na vida política nacional. Preferências judiciais restritivas podem restringir o papel do tribunal, mesmo quando as outras variáveis apontem na direção oposta. Esse argumento é desenvolvido a partir de análises da jurisprudência restritiva que o tribunal adotou, logo após a promulgação da Constituição, quanto aos seus poderes em controle abstrato de constitucionalidade. Embora o STF tenha saído da Assembléia Nacional Constituinte com uma ampla e significativa gama de poderes, alguns deles foram deliberada e temporariamente desativados ou adormecidos pelo tribunal no início dos anos 90 . A análise indica que, no Brasil, preferências judiciais restritivas se combinaram com interpretação constitucional para gerar e estabilizar jurisprudência autorestritiva que efetivamente limitou o impacto das variáveis exógenas discutidas na literatura existente. Assim, o querer de uma dada maioria no STF, pode afetar o desenho institucional e, com isso, influenciar o grau final de participação do tribunal no processo político decisório em um dado momento.

Palavras-chave: Comportamento Judicial, Preferências Restritivas, Desenho institucional, Judicialização da Política, Interpretação Constitucional, Mudança Constitucional.

\begin{abstract}
In the numerous explanations about the reasons that lead the Brazilian Supreme Court (STF) to take on a protagonist role in national politics, there is a certain inclination to focus on variables and processes that are external to the Court's Ministers. Institutional design, constitutional texts, social expectations and the strategic behavior of political players are some of these factors. However, although these exogenous variables might be important to explain the Tribunal's growing participation in the country's institutional and political scenario, they are not sufficient to explain some of the transformations the Supreme Court went through, from the 1990's to present day. This research argues that the choices made by the Ministers on how to exert their power and how much power they should have in the first place, may interact with exogenous variables consequently determining the intensity of the Court's participation in the country's political scene. Restrictive preferences for example, may constrain the Tribunal's role in a given case, despite the existence of external variables in the opposite direction. The research is based on decisions made by the Supreme Court short after the Constitution was enacted in 1988. In spite of the fact that the new Document amplified the Court's power and functions, some of these roles were kept dormant or deactivated by the STF. The analysis indicates that, in Brazil, judicial preferences were combined with constitutional interpretations to generate and stabilize an auto restrictive precedent pattern that effectively limited that impact of exogenous variables. Therefore, the will of a given majority of Ministers may indeed affect the Court's institutional design and thus influence the Court's participation in legal-political process.
\end{abstract}

Keywords: Legal Behavior; Restrictive Preferences; Institutional Design, Constitutional Interpretation 


\section{Introdução}

A formulação de políticas públicas no Brasil vem sendo afetada de maneira frequente e significativa por decisões judiciais, em especial do Supremo Tribunal Federal. ${ }^{2}$ Observadores, críticos e defensores do Tribunal divergem em relação às implicações normativas desse seu novo papel de destaque. Sua importância para a compreensão do processo político decisório nacional, no entanto, parece ser um denominador comum e relativamente incontestado. "Judicialização da política" tem sido a expressão mais frequente, na academia nacional, para designar a crescente participação judicial, em especial do STF, na decisão de questões típica e tradicionalmente decididas na esfera de atuação dos poderes eleitos. ${ }^{3}$ Muitas das interpretações existentes sobre como chegamos a esse cenário de acentuado protagonismo judicial possuem um traço comum: tendem a enfatizar o papel de variáveis e processos que independem da vontade dos Ministros do STF.

Entre os fatores tipicamente utilizados na construção de explicações para a judicialização da política que vivenciamos hoje no país, é frequente encontrar: (i) a canalização, para o Judiciário, de expectativas sociais frustradas diante de um Legislativo e um Executivo insuficientemente responsivos; ${ }^{4}$ (ii) o redesenho do sistema Brasileiro de controle de constitucionalidade na Constituição de 1988, ampliando não apenas o poder de controle do STF, como também os canais pelos quais diferentes atores políticos e sociais poderiam provocar a atuação do Tribunal;, (iii) a "constitucionalização abrangente", com a adoção de um texto constitucional simultaneamente amplo e detalhado, pavimentando o caminho para que diversas questões antes consideradas políticas sejam tratadas como judicializáveis; ${ }^{6}$ (iv) o comportamento estratégico por parte de atores políticos que vêem na interven-

2 Taylor, 2008.

3 Neste trabalho, partindo da definição de Tate (1995), chamo de "judicialização da política" o processo pelo qual o poder judiciário passa a decidir questões anteriormente decididas na esfera política (ou tipicamente entendidas como questões que deveriam ser decididas na esfera política). Para definições e exemplos, ver Castro, 1997. É preciso registrar, porém, que a expressão é empregada em sentidos ligeiramente diferentes, por autores diferentes, na análise do caso brasileiro (ver, por exemplo, Taylor (2008) e Vianna et al (2007)).

$4 \quad$ Vianna et al, 2007.

5 Carvalho, 2010.

6 Barroso, 2009; 2010. ção judicial a chance de reverter decisões desfavoráveis em arenas decisórias majoritárias, como o Congresso Nacional; ; por fim, (v) a crescente consolidação da democracia no país, que amplifica todos os fatores acima, ao mobilizar a cidadania na busca por mecanismos para fazer valer seus direitos e fortalecer o judiciário como ator relativamente independente da atuação das forças políticas do momento. ${ }^{8}$

Todos esses elementos são indiscutivelmente relevantes para compreender como é possível que um tribunal passe das margens da relevância política para o centro da vida pública no país em pouco mais de duas décadas. Todos, porém, constituem variáveis exógenas à composição do STF. Sua presença e seus efeitos parecem quase independer das atitudes, das aspirações, das ideias e até mesmo das decisões de quem integra o tribunal em um dado momento. São fatores que formam o cenário político-institucional que é considerado dado ao tribunal, $\mathrm{e}$ sobre o qual, a princípio, há pouco ou nada que os Ministros do STF possam fazer. Nessa perspectiva, Barroso, por exemplo, afirma que as circunstâncias que colocaram o Supremo Tribunal Federal no centro da política nacional estão ligadas "à Constituição, à realidade política e às competências dos Poderes", e que "[a] judicialização, que de fato existe, não decorreu de uma opção ideológica, filosófica ou metodológica da Corte. ${ }^{9}$ Nessa visão, os Ministros em si - sua crenças políticas e morais, sua concepção de como o STF deve atuar - não são necessariamente relevantes para a produção de um estado de coisas no qual o tribunal participa mais intensamente do processo político nacional. Os Ministros são primariamente observadores de um mundo que se transforma ao redor deles e os lança, de forma aparentemente irresistível, para o centro de debates políticos. Parecem não ter escolha: foram chamados a participar de decisões políticas e devem atender à convocação. ${ }^{10}$

Este trabalho procura indicar a insuficiência desse tipo de narrativa para se compreender exatamente como

7 Taylor \& Da Ros, 2008; Carvalho, 2004.

8 Barroso, 2009; Carvalho, 2004.

9 Barroso, 2009, p.02.

10 Ver Barroso, 2010, p.08, observando que a judicialização da política é "uma circunstância decorrente do desenho institucional vigente, e não uma opção política do Judiciário. Juizes e tribunais, uma vez provocados pela via processual adequada, não têm a alternativa de se pronunciarem ou não sobre a questão." 
chegamos ao cenário que Vieira chamou de "Supremocracia.". A construção da participação do STF no processo político-decisório no Brasil não pode ser plenamente explicada apenas com fatores exógenos à composição do STF. Mais especificamente, embora o desenho institucional, as expectativas sociais e o comportamento dos atores políticos sejam condições importantes - talvez até necessárias - para um cenário em que o tribunal participa intensamente do processo político decisório nacional, não parecem ser condições suficientes para determinar o grau exato dessa participação em um dado momento. É preciso levar em conta se e como as preferências dos Ministros do STF sobre como exercer o poder de que dispõem - e inclusive sobre de quanto poder deveriam dispor - interagem com as já mencionadas variáveis exógenas para explicar a intensificação do processo de judicialização dos anos 90 para cá. Se aceitamos que o desenho institucional - os poderes de que o tribunal dispõe em um dado momento - condiciona o efeito de variáveis como as expectativas sociais e as estratégias de atores políticos, é preciso considerar a possibilidade de uma dada composição do tribunal transformar, de maneira duradoura, os seus próprios poderes. Longe de serem vítimas, espectadores ou simples convidados, os Ministros do STF precisam ser encarados como agentes do processo de construção e transformação do poder do tribunal.

Essa constatação soa pouco problemática quando estamos tratando de processos de expansão de poderes de um tribunal. Estamos razoavelmente acostumados a imaginar que, em certos momentos e condições, juízes vão usar o poder de dizer o que a Constituição significa para ampliar os poderes da sua instituição. Neste trabalho, porém, enfatiza-se o cenário contrário. Em alguns aspectos-chave da estrutura do controle de constitucionalidade, a trajetória do Supremo Tribunal Federal na transição brasileira à democracia, da Assembleia Constituinte até o início dos anos 90, mostra como a interpretação constitucional pode estar a serviço da restrição estrutural de poderes do tribunal. Embora o STF tenha saído da Assembléia Nacional Constituinte com uma ampla e significativa gama de poderes para participar de forma cada vez mais efetiva da vida política no país, alguns desses poderes foram deliberada e temporariamente desativados ou adormecidos pelo tribunal em algumas de suas primeiras

11 Vieira, 2008 decisões importantes após a promulgação da Constituição de 1988.

O trabalho está estruturado em três outras seções. A seção II consiste em uma breve reconstrução de dois conjuntos de decisões do Supremo Tribunal Federal, envolvendo o alcance do controle abstrato de constitucionalidade, adotadas logo após a transição para a democracia. Pretende-se mostrar que, por meio do poder de interpretação constitucional conferido pela própria Constituição, o STF reconfigurou o desenho constitucional original e restringiu temporariamente o alcance de sua atuação na esfera política. Ao fazê-lo, contribuiu para manter a sua participação no processo político em um nível menor do que o esperado, caso fossem levadas em conta apenas variáveis exógenas. Na seção III, são discutidas algumas hipóteses para explicar porque os Ministros do STF teriam deliberadamente limitado seu próprio poder no período analisado, já que é aparentemente contraintuitivo que membros de qualquer instituição política prefiram ter menos poder. Na seção IV, retornaremos ao debate sobre judicialização da política. Procurarei sistematizar conceitualmente as implicações, para estudos sobre judicialização no Brasil, da constatação de que preferências judiciais restritivas podem ser transformadas em desenho institucional estável por meio de interpretação constitucional. O caso brasileiro sugere que variáveis ligadas à composição do Tribunal em exame podem contribuir para produzir graus bastante distintos de judicialização. A seção IV conclui a análise.

\section{Preferências judiciais restritivas no Supremo Tribunal Federal pós-Constituinte}

\subsection{Interpretação como mecanismo de expansão e restrição do poder judicial}

É difícil negar que, nas últimas três décadas, a participação do Supremo Tribunal Federal no processo decisório político nacional cresceu. ${ }^{12}$ Essa constatação trivial

12 Ver, por exemplo, Vieira (2008). Há debates em aberto, porém, sobre a exata natureza e a extensão da participação do Supremo na política nacional. Compare-se, por exemplo, Vieira (2008) e Pogrebinschi (2012). Para uma discussão sobre os componentes institucionais que geravam uma “judicialização controlada" na vigência da constituição de 1967, ver Carvalho (2010). 
gera questões importantes. Por que o observamos esse aumento do exercício de poder, por parte do tribunal, sobre questões que tradicionalmente seriam resolvidas na esfera política? Em especial, como explicar o timing da mudança, dos anos 90 para cá, no peso da instituição na vida política do país? A Constituição já estava em vigor na época, com seus dispositivos ambiciosos, abrangentes e detalhados, tanto quanto hoje. Se o texto constitucional - que consagra o STF como "guardião da Constituição" - fosse suficiente para explicar, justificar e alimentar o protagonismo do Supremo, deveríamos ter acabado de celebrar duas décadas de constante e intensa participação do STF na política. Não é este o caso. A força do Supremo no cotidiano político Brasileiro é um fenômeno relativamente recente, apesar de a consagragação formal do papel de "guardião da Constituição" datar do final dos anos 80. Esse cenário sugere que qualquer combinação de variáveis explicativas que já estivessem presentes no período subsequente à promulgação da Constituição é insuficiente para produzir, por si só, o grau de judicialização da política que observamos hoje. Parece ser este o caso do que chamei, na seção anterior, de variáveis “exógenas”. Afinal, essas variáveis - desenho institucional, democratização, demandas sociais, comportamento estratégico dos atores políticos - já estavam em larga medida presentes nos anos 90. Na época, porém, a presença do STF na tomada de decisões políticas era bem menos visível. Quais outros fatores, então, podem se combinar com essas variáveis exógenas para explicar o crescimento dessa presença judicial na vida política do Brasil, dos primeiros anos após a promulgação da Constituição até hoje?

A hipótese é a de que os próprios Ministros do $\mathrm{Su}$ premo estabeleceram certos limites ao quanto o Supremo poderia participar do processo decisório político. Juízes podem ter inclinações mais ou menos favoráveis ao exercício de poder, pelo tribunal, na esfera política. E uma maioria de Ministros que não queira exercer todo o poder de que dispõe tem meios para se proteger do seu próprio poder, restringindo-o. Nesse tipo de cenário, ainda que as variáveis exógenas apontem no sentido de uma expansão do papel do tribunal, pode-se observar uma atuação mais modesta por parte do STF na esfera política. O mecanismo para converter preferências restritivas em desenho institucional foi a interpretação constituição. Da mesma forma que podem intepretar a constituição para aumentar seu poder, quando querem participar de forma mais intensa da vida política do país, tribunais como o STF podem ler o texto constitucional de forma a restringir suas oportunidades de participar de decisões políticas, na prática reduzindo o poder que lhes fora atribuído pelos constituintes de 1988 .

Texto constitucional, desenho institucional e competências dos poderes são variáveis que, dependendo do contexto político, guardam entre si uma relação de mútua implicação. São analiticamente separáveis, mas, na prática, dado um mínimo de independência judicial e um conjunto inicial de poderes de judicial review, esses elementos influenciam-se reciprocamente. A dotação inicial de competências de que cada instituição dispõe, de acordo com o texto constitucional, é ao mesmo tempo regra do jogo e parte do que está em jogo nas interações entre esses poderes. ${ }^{13}$ No dia-a-dia da política e da implementação da constituição, os diversos poderes (em especial, mas não exclusivamente, o Judiciário) podem interpretar a constituição vigente de modo a expandir e retrair essas competências, ou até mesmo a inventar competências inteiramente novas. ${ }^{14}$

Assim como tribunais com frequência procuram ampliar seu estoque inicial de competências por meio de

13 Cf, por exemplo, no caso do Brasil, a interpretação de Falcão e Lennertz (2008) da separação de poderes pós-1988 como competição, e não harmonia, nem subordinação, entre Judiciário, Legislativo e Executivo. Isto não significa dizer que poderes estejam sempre em oposição um ao outro. Tampouco que as interações entre essas instituições sejam sempre e necessariamente jogos de soma zero. Mas é inegável que, a partir de um desenho institucional inaugurado pela Constituição de 1988, os três Poderes da República frequentemente estarão disputando a palavra final sobre questões políticas importantes - e o próprio poder de dar a palavra final sobre questões futuras.

14 Ver Ginsburg (2003) capítulo III. Um exemplo clássico é o conjunto de decisões tomadas pelo Conselho Constitucional Francês entre 1971 e 1973, em que o Conselho começou a incorporar, no "bloco constitucional" do país, direitos fundamentais previstos nos preâmbulos das constituições francesas anteriores e até mesmo na Declaração Universal dos Direitos do Homem e do Cidadão promulgada em 1789 - ainda que a inclusão de uma lista de direitos houvesse sido expressamente rejeitada na elaboração da constituição da Quinta República. Esse completo redesenho institucional do controle de constitucionalidade foi comparado por Stone Sweet (2007) a um “coup détat jurídico". Ver também Moe e Howell (1999), argumentando que o poder do Presidente nos EUA tende a crescer por meio de interpretações expansivas unilaterais que os ocupantes do cargo podem fazer dos [modestos] poderes formalmente previstos no texto original da constituição. 
interpretação constitucional, podem também usar seu poder interpretativo no sentido de restringir a dotação de competências previstas no texto constitucional original. ${ }^{15} \mathrm{~A}$ direção expansiva ou restritiva da intepretação depende, antes de mais nada, do que os Ministros queiram fazer. ${ }^{16}$ Nas próximas seções, argumentarei que, no Brasil, no período imediatamente após a promulgação da Constituição, é possível ver em ação mecanismos judiciais interpretativos do tipo restritivo. Pode-se observar Ministros do Supremo firmando interpretações constitucionais que reconfiguravam para menos poderes de que dispunham segundo o texto da Constituição de 1988.

Esta narrativa não ignora que os Ministros do STF lutaram de várias formas para preservar e expandir o poder da instituição durante a transição. No período da Constituinte, os Ministros procuram consolidar, perante a opinião pública em geral, a posição do STF como um poder de Estado que estava à altura da responsabilidade política decorrente desse papel. ${ }^{17}$ Mesmo assim,

15 Talvez o exemplo mais famoso de expansão de poder judicial via interpretação seja o do caso Marbury vs. Madison, decidido pela Suprema Corte dos EUA em 1803. O presidente da Corte, John Marshall, agradou ao então Presidente dos EUA, Thomas Jefferson, ao negar que a Corte tivesse competência para ordenar que o governo empossasse o juiz Marbury, nomeado no apagar das luzes do mandato do presidente anterior. Contudo, na fundamentação da decisão, Marshall anunciou que cabia ao Judiciário declarar inconstitucionais leis regularmente adotadas pelo Congresso Nacional - um poder que não estava explícito no texto constitucional.

16 Isto não equivale a dizer que o "querer" dos Ministros é condição suficiente para qualquer expansão ou restrição do poder judicial. Por mais que regras constitucionais e entendimentos sobre os limites da atuação de cada um dos três poderes possam ser reinterpretados, em certas condições há barreiras políticas e até mesmo jurídicas de difícil superação. No caso das restrições jurídicas, regras de competência expressamente contrárias ao movimento de expansão podem ser bastante eficazes em minimizar ou anular o impacto final de preferências judiciais expansivas. Um exemplo bastante eloquente na experiência constitucional brasileira foi a reforma constitucional de 1926, aprovada para impedir que habeas corpus continuasse sendo usado de maneira expansiva para judicializar atos políticos arbitrários de forma mais geral, e não apenas violações do direito de ir e vir. Essa emenda pôs fim à chamada "doutrina brasileira do habeas corpus." Dessa forma, um movimento judicial de expansão do escopo do seu poder (uma variável endógena) foi contido pela alteração do texto constitucional (uma variável exógena) no sentido de deixá-lo mais detalhado e dificultar interpretações expansivas. Sou grato a Andres Del Rio por chamar a minha atenção para esse ponto e para esse exemplo.

17 Oliveira, 2004 no mesmo período, houve manifestações de Ministros expressando desconforto com a aproximação entre poder judicial e poder político que é típica do controle abstrato de constitucionalidade. ${ }^{18}$ Anos depois, na implementação da recém-promulgada Constituição, essas manifestações deram lugar a restrições jurisprudenciais de competências que haviam sido ampliadas pelo texto constitucional. Para os fins deste trabalho, explorarei esse processo de autorestrição via jurisprudência no tocante a duas propriedades do desenho institucional do controle de constitucionalidade que são tipicamente consideradas como facilitadoras da expansão do poder judicial: (a) o número de atores que podem iniciar o controle de constitucionalidade e (b) o conjunto das normas que podem ser objeto desse controle.

\subsection{Interpretações restritivas do controle abstrato de constitucionalidade na jurisprudência do STF}

Sendo tipicamente inertes - isto é, por dependerem da provocação de outros atores institucionais ou sociais para que possam atuar -, Tribunais precisam de oportunidades de manifestação. As unidades mais básicas de construção dessas oportunidades são os casos levados ao tribunal: quanto mais atores puderem levar questões ao tribunal, mais oportunidades a instituição terá para construir, sustentar e exercer seu poder. Sem casos, não há judicialização - e quanto mais amplo for o leque de atores insatisfeitos com decisões políticas majoritárias capazes de provocar a atuação do tribunal constitucional, mais oportunidades o tribunal terá de construir e exercer seu poder. ${ }^{19}$ Por isso, um tribunal com regras

18 Ver tópico II.2.1, infra.

19 Trata-se de um ponto reconhecido tanto por defensores, quanto por críticos da expansão do poder judicial, em diferentes sistemas jurídicos. Aharon Barak, ex-Presidente da Suprema Corte de Israel e mundialmente reconhecido como um juiz ativista, observou que "if we liberalize the tests for standing [isto é, se flexibilizarmos as regras referentes a quem pode (e como pode) provocar uma decisão do tribunal], we will usher in a new era for judicial decision-making whose ramifications are far greater than the issue of standing itself." (2006, p.190) Partindo dessa constatação, Barak observa ainda que a maneira pela qual um juiz aplica as regras que determinam quem e como pode ter acesso à jurisdição do tribunal (isto é, regras de standing perante o tribunal) é um bom indicador da concepção de atuação judicial (mais ou menos expansiva) que esse juiz adota. Juízes com concepções mais tímidas tenderam a valorizar 
que dificultem a chegada de casos e questões que provoquem sua decisão tende - ceteris paribus - a ter um poder menor, na esfera política, do que um tribunal que opera com regras mais generosas. ${ }^{20} \mathrm{O}$ fluxo de casos é, enfim, um elemento essencial na definição das chances que um tribunal tem de exercer qualquer poder relevante em uma dada comunidade. O STF atua dentro de uma agenda construída por ações ajuizadas pela sociedade (isto é, sua agenda institucional é formal e primariamente exógena, em contraste à dos outros poderes de Estado). Isso não quer dizer que tribunais não possam ter - como, aliás, frequentemente têm - um significativo grau de autonomia sobre a construção de sua pauta e sobre o timing de suas decisões. Contudo, mesmo quando há essa relativa margem de manobra, ela ocorre nos limites de um conjunto inicial de casos que é dado por agentes externos. $\mathrm{O}$ poder dos tribunais de formular sua agenda institucional é, na melhor das hipóteses, negativo: dentro do conjunto total de casos que recebem, podem priorizar alguns casos e temas em detrimento de outros, mas não podem livremente buscar casos e temas fora da pauta inicial exógena, trazida pelos litigantes. Essa restrição é sintetizada na idéia de inércia judicial.

mais essas exigências procedimentais, enquanto juízes que consideram que sua função requer um papel mais ativo em um sistema democrático tenderão a flexibilizar essas regras (2006, p.192-193). No mesmo sentido, o moderado Lewis Powell, ex-Ministro da Suprema Corte dos EUA que dificilmente poderia ser considerado um ativista judicial, observou no caso United States v. Richardson (418 U.S. 166, 1974) que a flexibilização de regras de standing está diretamente relacionada à expansão do poder judicial.

20 Ver Ginsburg (2003, pp.36-37 e seguintes). Fisher (1988, p.85) observa que a flexibilização de regras de acesso à Corte tipicamente abre caminhos para um exercício mais agresssivo de poder. Por isso, diferentes regras de acesso produzem estratégias diferentes de acionamento do judiciário por parte de atores políticos e, consequentemente, diferentes padrões de relação entre o tribunal e a política. Ver, por exemplo, Rios-Figueroa \& Taylor (2006), p.753 (observando que "Standing [legitimação para demandar uma decisão judicial sobre um dado tema] is perhaps the most influential means by which institutional structure can predetermine the judicial influence of specific policy actors. Differences in standing have an impact not only on the types of plaintiffs heard but also - and this is important because it directly affects strategies of policy judicialisation - in the number of ways the same topic can be raised in the courts") e 765 (concluindo, após análise de padrões do uso de judicial review por atores políticos no Brasil e no México, que "patterns of judicial involvement in policy change depend on the number of different ways the same issue can reach the courts").
Em sentido semelhante, as regras que definem o que pode ser objeto do controle de constitucionalidade também modulam as oportunidades de manifestação, construção e exercício de poder político por parte do tribunal. Mantendo mais uma vez constantes os outros elementos do desenho institucional e do contexto político, é possível afirmar que um tribunal que pode se pronunciar apenas sobre certo tipo de leis (por exemplo, apenas leis infraconstitucionais, e não emendas constitucionais), ou que pode efetuar o controle de sua constitucionalidade apenas dentro de certo prazo, tende a ser menos poderoso do que um tribunal que não opere dentro dessas restrições. ${ }^{21}$

Nesta seção, observaremos como, no Brasil pós-constituinte, com relação ao acesso e ao objeto dos mecanismos de controle direto e abstrato de constitucionalidade, o STF realizou construções jurisprudenciais que limitaram, em um primeiro momento, o alcance do poder do tribunal sobre questões políticas. Os primeiros leading cases do tribunal quanto a esses elementos definidores do seu próprio poder de participar da vida política do país foram no sentido de desativar poderes previstos no texto constitucional recém-promulgado.

\subsubsection{Acesso ao Controle Abstrato}

O primeiro desses elementos jurisprudencialmente reconstruídos é o conjunto de regras que define quem pode propor Ações Diretas de Inconstitucionalidade (ADIs). Uma das mais celebradas inovações da Constituição de 1988 foi a ampliação do leque de legitimados para provocar uma decisão do STF em controle abstrato de constitucionalidade. ${ }^{22}$ De 1965 a 1988, o instrumento existente para controle abstrato - a representação de inconstitucionalidade, precursora da atual ADI - estava única e exclusivamente nas mãos do Procurador da República, que era demissível ad nutum pelo Presidente e, segundo jurisprudência consolidada, tinha ampla discrionariedade para decidir se iniciava ou não o processo de controle junto ao STF. Na prática, isso fazia com que questões politica-

21 Novamente, esta é uma proposição geral que encontra sustentação em estudos de caso e análises comparadas. (Stone, 1992; Stone Sweet, 2000; Ginsburg, 2003), bem como em discussões teóricas sobre processos de judicialização (Stone Sweet, 2008, p.234-235).

22 Barroso, 2006, p.140. 
mente delicadas do ponto de vista do Poder Executivo não fossem submetidas à apreciação do STF, limitando assim de forma significativa o grau de judicialização que poderia ocorrer na política brasileira. ${ }^{23}$ Nesse cenário, o artigo 103 da Constituição de 1988 representou a principal porta de entrada de demandas sociais e de minorias parlamentares na agenda do Supremo Tribunal. ${ }^{24}$

Entretanto, no direito constitucional vigente no país, o texto do artigo 103 não é o fim da história para se determinar quem pode propor ADIs e provocar a atuação do STF em sede de controle abstrato de constitucionalidade. Logo nos primeiros anos após a promulgação da Constituição, uma série de decisões do tribunal restringiu de forma significativa a abertura imaginada e positivada pelos constituintes. Ao ler o artigo 103, o STF criou uma distinção que não havia sido feita pelos constituintes. Distinguiu legitimados "universais" (que poderiam propor ADI sobre qualquer tema) e legitimados "especiais" (que só poderiam propor ADI sobre temas ligados à sua esfera de atuação), entre os quais foram incluídas as "confederações sindicais" e "entidades de classe de âmbito nacional" previstas no inciso IX do artigo 103 da Constituição. ${ }^{25}$

Nessa construção jurisprudencial sem base expressa no texto constitucional, uma confederação sindical ou entidade de classe de âmbito nacional só poderia propor ADIs que envolvessem atos normativos com "pertinência temática" em relação aos propósitos e linhas de atuação da associação. ${ }^{26}$ Além disso, o STF construiu uma série de requisitos para que uma associação que se apresente como "entidade de classe de âmbito nacional" possa invocar para si a legitimação ativa prevista no art. 103, IX: primeiro, todos os filiados à entidade precisam exercer a mesma atividade econômica ou profissional; segundo, não podem propor ADI as entidades cujos membros sejam pessoas jurídicas (as chamadas "associações de as-

23 Carvalho, 2010, p.187.

24 Carvalho, 2010; Vianna et al, 2007.

25 Ver, p.ex., o julgamento na Medida Cautelar em Ação Direta de Inconstitucionalidade n.138-8-RJ, julgada em 14.02.1990.

26 Nas palavras de Barroso (2006, p146-147), para o STF, “é preciso que haja uma relação lógica entre a questão versada na lei ou ato normativo a ser impugnado e os objetivos sociais da entidade requerente. Vale dizer: a norma contestada deverá repercutir direta ou indiretamente sobre a atividade profissional ou econômica da classe envolvida, ainda que só parte dela seja atingida". sociações") $)^{27}$; por fim, a entidade deve possuir membros em, no mínimo, nove Estados. ${ }^{28}$ Essas construções - que, vale insistir, foram feitas independentemente de base textual expressa na Constituição ${ }^{29}$ - resultaram em uma relativa restrição do grau de representatividade e abertura do controle abstrato de constitucionalidade no Brasil. ${ }^{30}$

É interessante notar que antes e durante os trabalhos da Assembleia Nacional Constituinte (ANC) a maioria dos Ministros do STF da época revelou preferir um acesso restrito ao controle abstrato, concentrado e por via direta. Em 1986, o Supremo Tribunal Federal enviou mensagem pública, formal e oficial à Comissão Afonso Arinos, que havia acabado de ser convocada pelo Presidente José Sarney para elaborar um projeto de constituição. Entre as inúmeras recomendações constantes daquela mensagem, afirmaram os Ministros:

“Quanto à pretendida outorga de legitimidade para representação por inconstitucionalidade de lei ou ato normativo federal ou estadual a certos órgãos do Poder Público (Executivo, Legislativo e Judiciário) ou, mesmo, a entidades de direito público ou privado, entendeu a Corte que ela deve continuar a cargo, exclusivamente, da Procuradoria-Geral da República. Se se entende que seu titular fica excessivamente vinculado ao Poder Executivo, diante da demissibilidade "ad nutum", então será caso de pô-la em discussão, com eventual outorga de garantias maiores para o exercício do cargo. Isso, porém, deve ser considerado, com maior segurança, pelo próprio Poder Constituinte, abstendo-se a Corte de outras considerações por envolverem temas ligados aos Poderes Executivo e Legislativo." 31

27 Essa restrição foi atenuada em decisões posteriores (ver Barroso, 2006, p.145-146)

28 A leitura da primeira parte do dispositivo ("confederações sindicais") também foi restritiva, mas não tão drástica, nem tão inventiva quanto a que ocorreu com as "entidades de classe de âmbito nacional". Sobre o tema, e com uma análise detalhada de toda a jurisprudência relevante na aplicação do art. 103, IX, ver Ferreira, 2009. Ver também Barroso, 2006, p.145-148, com indicações de inúmeros precedentes.

29 Ver, nesse sentido, Barroso, 2006, p.141 e 148. O autor registra ainda que a legitimaçao das "entidades de classe de âmbito nacional" tem sido especialmente polêmica, envolvendo "um conjunto amplo de discussões, todas gravitando em torno da posição severa e restritiva adotada pelo Supremo Tribunal Federal na matéria" (p.145-146).

30 Ferreira, 2009, p.220-221.

31 "Sugestões do Supremo Tribunal Federal à Comissão Provisória de Estudos Constitucionais", documento publicado no jornal Estado de São Paulo em 03 de agosto de 1986. O STF também se colocou publicamente contra a perda de sua competência relativa à uniformização da aplicação da 
O tom da mensagem é cauteloso, mas sugestivo das preferências da maioria dos membros do tribunal antes da convocação da ANC, em fevereiro de 1987. Para o Supremo da transição, ampliar o rol de legitimados a iniciar essa espécie de controle de constitucionalidade não era uma boa idéia. Em julho de 1987, já durante trabalhos da ANC, o Ministro José Carlos Moreira Alves - uma inegável liderança intelectual no STF até sua aposentadoria em 2003 - se manifestou inequivocamente contra a expansão da legitimação para iniciar o controle abstrato e por via direta. ${ }^{32}$ Em palestra proferida em um congresso nacional de direito constitucional, Moreira Alves afirmou que o projeto de constituição que então tramitava na ANC "abre demais o acesso sobre quem pode representar a inconstitucionalidade de uma lei, prevê que onze órgãos políticos, incluindo todos os governadores de Estado, podem provocar inconstitucionalidade". "É demais", concluiu o Ministro. ${ }^{33}$

Apesar de não ter sido bem sucedido em obter da ANC o seu arranjo ideal em termos das regras para acesso ao controle abstrato e concentrado, o STF conseguiu, pela via da jurisprudência, aproximar de suas preferências derrotadas o desenho institucional. Limitou-se

legislação federal, expressa na proposta de criação do Superior Tribunal de Justiça.

32 O Ministro José Carlos Moreira Alves teve um papel central na formação da jurisprudência (primariamente restritiva) do STF quanto aos seus próprios poderes em sede de controle abstrato de constitucionalidade no Brasil. Para análises da liderança do Ministro Moreira Alves na construção do entendimento majoritário no STF sobre judicial review nos anos 80 e 90, ver Mendes, 2004, e Campos, 2012. Vale notar que o tema da restrição da atuação do STF em sede de controle abstrato era um tema particularmente caro ao Ministro. De fato, Moreira Alves publicou trabalhos acadêmicos durante e após o processo de aprovação do texto constitucional criticando o texto constitucional nesse aspecto e defendendo que o recurso a mecanismos de controle concentrado e abstrato de constitucionalidade no Brasil deveria ser restrito (Moreira Alves, 1988; 1996).

33 Trechos extraídos da reportagem "Para ministros do STF, mecanismos de controle devem sofrer mudanças", Folha de São Paulo, 10/07/1987. Vale registrar que, no mesmo evento, o Ministro Néri da Silveira, então Vice-Presidente do tribunal, adotou uma posição mais simpática à expansão da lista de legitimados, que, segundo o Ministro, "poderia ser ampliada, estendendo-se do procurador-geral da república, como é atualmente, aos chefes dos poderes Executivo, Legislativo e mesas dos partidos". Mas mesmo essa visão atenuada não era favorável à inclusão de organizações da sociedade civil - que, apesar das reservas de Ministros do STF, acabaram sendo incluídas pela ANC no artigo 103 do texto aprovado. o grau de abertura do controle de constitucionalidade à sociedade e, com ele, a própria pauta do STF. Mantendo constantes outras variáveis, se menos atores podem ajuizar ADIs, menos questões políticas tendem a chegar ao STF pela via direta.

\subsubsection{Objeto do Controle Abstrato}

Outro aspecto do desenho do controle de constitucionalidade no Brasil que foi redefinido de forma significativa pela jurisprudência do STF no início dos anos 90 diz respeito ao objeto das Ações Diretas de Constitucionalidade. Segundo o artigo 102, I, (a) da Constituição, compete ao STF julgar "a ação direta de inconstitucionalidade de lei ou ato normativo federal ou estadual". Contudo, quando se deparou com uma ADI que versava sobre lei anterior à Constituição de 1988, a maioria dos Ministros entendeu que a expressão "inconstitucionalidade" se referiria apenas à relação de contrariedade entre a constituição e uma lei posterior. Por sua vez, nessa perspectiva, a contrariedade entre lei anterior e a constituição nova deve ser resolvida no plano da revogação, e não da inconstitucionalidade.

Essa discussão teórica possuía grandes implicações práticas, já que, logo após a transição, a maioria esmagadora das leis em vigor no país tinha sido aprovada antes da promulgação da Constituição. Mais ainda, várias dessas leis haviam sido adotadas pelo regime militar que há pouco saíra de cena. Algumas eram especialmente problemáticas na transição para um regime democrático, como, por exemplo, a Lei n.5250/1967 (Lei de Imprensa). A discussão sobre como o STF poderia se manifestar sobre grande conjunto de leis pré-constitucionais foi travada no âmbito da ADI 02, proposta em 1989, e cujo julgamento foi concluído em 1992. Segundo a maioria dos Ministros, que acompanhou o voto do Ministro Paulo Brossard, a previsão constitucional referente às Ações Diretas de Inconstitucionalidade não dava ao STF poder para julgar, em sede de ADIn, a compatibilidade de leis pré-constitucionais com a Constituição de 1988.

Tendo em vista os objetivos deste trabalho, não cabe aqui repassar toda a controvérsia doutrinária - dentro e fora do STF - que envolveu a tomada dessa decisão 
na ADI n.02. ${ }^{34}$ Mas é importante notar duas coisas sobre os debates que ocorreram no âmbito do STF sobre este tema. Primeiro, o julgamento da ADI n.02 não foi unânime. Pelo menos três Ministros (Sepúlveda Pertence, Marco Aurélio e Néri da Silveira) entenderam ser possível, sim, ajuizar ADIn pedindo ao STF que pronunciasse a inconstitucionalidade da legislação aprovada durante o regime militar. Isso pode ser interpretado como um indicador de que havia diante dos Ministros pelo menos duas respostas juridicamente plausíveis - uma mais restritiva do escopo da ação do STF, outra mais expansiva. ${ }^{35}$ Segundo, os participantes da discussão estavam conscientes de que, em que pese a seriedade com que esgrimiram argumentos técnicos para defender suas posições, o que estava em jogo no fundo era a definição do papel e da responsabilidade do STF na vida política do país naquele momento. Nesse sentido, logo na abertura de seu voto vencido, o Ministro Sepúlveda Pertence observou:

\begin{abstract}
"Tenho a ousadia de dissentir, por força de uma firme convicção de que recusar a via da ação direta de inconstitucionalidade ao expurgo das leis velhas incompatíveis com a nova ordem constitucional seria demitir-se, o Supremo Tribunal Federal, de uma missão e de uma responsabilidade que são suas. Intransferivelmente suas." ${ }^{36}$
\end{abstract}

Apesar da manifestação do Ministro Pertence, e assim como ocorreu nas construções jurisprudenciais envolvendo as restrições na legimitação ativa para propor ADIn, também aqui uma maioria de Ministros optou por diminuir, ainda que pontualmente, o alcance do poder

34 Para uma análise dos votos e principais argumentos dos Ministros Paulo Brossard, que defendeu a tese (afinal vencedora) da revogação e inadmissibilidade de ADIn em casos de lei anterior à Constituição, e Sepúlveda Pertence, que defendia que o STF deve julgar ADIns inclusive contra leis pré-constitucionais, ver Andrade, 2009.

35 Vale notar que esse uso da distinção entre revogação e inconstitucionalidade para restringir o objeto do controle abstrato e concentrado de constitucionalidade já havia sido formulado pelo tribunal ainda na vigência da Constituição de 1967/69. No julgamento da Representação de Inconstitucionalidade n. 1.012, em acórdão elaborado pelo Ministro Moreira e publicado no Diário Oficial de 05.11.1979, o tribunal havia afirmado que: “(...) Em se tratando de leis anteriores à Constituição Federal vigente, não há que se cogitar - como tem entendido o S.T.F. - de inconstitucionalidade, mas, sim, (e se for o caso), de revogação, matéria estranha a representação de inconstitucionalidade." Sou grato a Carlos Alexandre de Azevedo Campos por me chamar a atenção para essa continuidade na jurisprudência do STF. que o tribunal recebera da própria Constituição para realizar controle abstrato e concentrado de constitucionalidade. É inegável que as decisões do STF nos casos acima mencionados restringiram o escopo de ação do tribunal sobre a política. Como discutido no início desta seção, o poder judicial é exercido a partir de uma pauta relativamente exógena, e, aqui, o STF exerceu seu poder de interpretar a constituição para restringir tanto o número de atores com acesso ao controle abstrato e concentrado, quanto o tipo de questões que poderiam ser objeto desse tipo de controle.

\section{Poder Não é Querer: explicando preferên- cias judiciais restritivas}

\subsection{Restrições jurisprudenciais como canalização e adiamento de demandas}

$\mathrm{Na}$ seção anterior, procurou-se mostrar que, por razões ainda não completamente investigadas, nos anos subsequentes à promulgação da Constituição, em diversos aspectos os Ministros do STF interpretaram de forma restritiva os amplos poderes que o texto constitucional lhes conferia. Mostrou-se também que havia correlações significativas entre essa jurisprudência restritiva e o desenho institucional que o tribunal parecia considerar "ideal" nos debates constituintes. ${ }^{37}$ Contudo, pode parecer estranho que uma instituição judicial atue no sentido não apenas de não exercer seu poder em casos específicos, mas também de diminuir suas próprias competências de maneira estrutural. Afinal, não é intuitivo que, em princípio, todo membro de uma dada instituição tenderá a preferir um estado de coisas em que essa instituição tenha mais poder a um estado de coisas em que ela possua menos oportunidades de exercer poder? Além disso, em inúmeras outras oportunidades nos anos imediatamente subsequentes à promulgação da Constituição, o STF tomou decisões de grande repercussão em que claramente ampliou ou reforçou as fronteiras do seu território em relação aos outros dois poderes. Um claro exemplo é a

37 Vale notar que não se tentou observar diretamente as preferências individuais dos Ministros que integravam o STF no período analisado, mas apenas inferir essas orientações a partir de decisões e pronunciamentos que apontavam na direção de diminuir as oportunidades e os recursos que o tribunal tinha para exercer poder. 
ADI 939-DF, julgada em 15/12/1993, na qual o Tribunal explicitou, articulou e justificou a sua competência para declarar inconstitucionais emendas à constituição regularmente aprovadas pelo Congresso Nacional. ${ }^{38}$ Como integrar todos esses elementos - alguns indicando expansão e outros, restrição - em uma narrativa que, além de tudo, contraria nossas intuições sobre como instituições políticas se comportam ao longo do tempo?

O primeiro passo para responder a pergunta acima é notar que as restrições jurisprudenciais discutidas na seção anterior são relativas. Limitam a pauta decisória do STF nas ADIns, mas deixam em aberto a possibilidade de o Tribunal decidir, pela via do controle incidental, (i) questões trazidas pelos atores excluídos do controle abstrato, (ii) inclusive sobre leis pré-constitucionais. ${ }^{39}$ Uma associação de classe que não preencha os requisitos da jurisprudência do STF para propor ADIn pode ainda assim ingressar na primeira instância da justiça comum e atacar uma lei anterior a 1988 cuja aplicação considere inconstitucional - e é possível que esse pedido acabe sendo de fato decidido em última instância pelo próprio STF. Por outro lado, é certo que, tanto para o STF, quanto para as partes, faz diferença se uma questão é levada ao tribunal pela via direta, como nas ADIns, ou por via incidental, como no caso dos Recursos Extraordinários. De fato, as decisões em sede de controle abstrato por via de ADIn possuem efeitos erga omnes, vinculantes para todo o território nacional, enquanto as decisões tomadas no âmbito de controle incidental tem efeitos apenas inter partes, isto é, vinculam apenas as partes envolvidas no conflito em

38 Esta decisão, porém, ocorreu mais de cinco anos após a promulgação da Constituição de 1988. Pode ser que, em 1993, tanto por mudança na composição do tribunal, quanto pela progressiva estabilização da política brasileira, o STF já estivesse mudando de posição em relação ao tipo de participação que deveria ter no cenário nacional. Cf. os tópicos III. 2 e III.3, infra.

39 Um exemplo interessante dessa dualidade também pode ser encontrado na postura adotada pelo STF no julgamento da Ação Direta de Inconstitucionalidade n. 223-6/DF, na qual se discutia a constitucionalidade de Medida Provisória proibindo a concessão de liminares em quaisquer mandados de segurança e procedimentos cautela que envolvem o Plano Collor. O STF entendeu que a MP em questão era constitucional em tese, ressalvando, porém, a possibilidade de ela ser inconstitucional em concreto, se aplicada a certos casos extremos. Dessa forma, o STF foi deferente à decisão política do Presidente, ao mesmo tempo em que manteve em aberto seu poder de apreciar a questão pela via incidental em casos futuros. meio ao qual se levantou a questão de inconstitucionalidade. ${ }^{40}$

Em geral, as questões que tramitam pela via concreta e incidental levam mais tempo para atingir o STF - e, quando afinal o fazem, geralmente chegam aos Ministros já tendo provocado vários outros pronunciamentos judiciais sobre aquele mesmo conjunto de temas. ${ }^{41} \mathrm{Na}$ prática, longe de uma simples abdicação de poder, o que o STF fez foi canalizar parte de sua pauta para mecanismos mais lentos de controle de constitucionalidade. Além disso, como essas restrições relativas foram implementadas em decisões do próprio STF, sem qualquer dispositivo legal que as tornasse necessárias ou obrigatórias, poderiam ser revistas a qualquer tempo, o que reforça ainda mais o seu caráter relativo e controlável pelo tribunal. ${ }^{42}$

Assim, as restrições relativas operadas pelo STF expressam mais uma aversão a exercer poder em controle abstrato e concentrado de constitucionalidade do que a exercer poder em geral. Mesmo se tivermos em mente essas considerações, porém, a pergunta permanece: por que Ministros do STF restringiram seu poder, ainda que de forma relativa? Por que jogaram para o controle incidental - de efeitos mais limitados e mais demorados do que o controle abstrato - demandas sociais que representariam grandes oportunidades de explicitar, reforçar e ampliar seu poder? Se o objetivo é aumentar o poder da instituição, não seria melhor ampliar ao máximo tanto o objeto do controle concentrado, quanto o número de pontos da sociedade pelos quais essas questões podem ingressar na pauta legítima do STF?

\subsection{Nova Constituição, Ministros Antigos?}

Uma primeira possível hipótese para explicar essas preferências restritivas quanto ao controle abstrato e concentrado parte da constatação da grande continuida-

40 Vale notar que, no período analisado, não existiam os institutos da Súmula Vinculante e da Repercussão Geral, que, de maneira geral, tendem a expandir a eficácia de posições adotadas pelo Supremo em decisões que, de outra forma, teriam efeito apenas inter partes.

41 Sobre os diferentes "tempos processuais" no STF , ver Alves, 2009 e Veríssimo, 2008.

42 Por certo, esse grau de flexibilidade só existe no Brasil porque, até o momento, não está consolidada no STF uma cultura forte de respeito aos seus próprios precedentes (ver Vojvodic et al, 2009). 
de judicial que marcou a transição brasileira. $\mathrm{O}$ fato de o STF ter se mantido praticamente intacto em sua composição durante a democratização, ainda que com competências ampliadas, pode ser relevante para se explicar esse resultado descrito nas seções anteriores. Tendo em vista que a transição de um regime autoritário para um regime democrático e a elaboração e implementação de uma nova constituição ocorreram à sombra de um tribunal cujos membros foram indicados pelo regime anterior, a presença de certos entendimentos mais tímidos em relação ao papel do STF talvez não seja tão surpreendente.

É plausível que Ministros da transição tivessem crenças sinceras sobre qual o papel adequado de uma Corte Suprema em um regime democrático. ${ }^{43}$ Como observado na seção anterior, em vários pontos essas crenças não correspondiam ao desenho institucional aprovado na Constituinte, em especial no que se refere à expansão dos mecanismos de controle abstrato e concentrado de constitucionalidade. Como já discutido na seção II, embora formalmente já houvesse controle abstrato de constitucionalidade no país desde 1965, por força da Emenda Constitucional n.16, tratava-se de poder de implicações bastante modestas. Somente o Procurador-Geral da República, demissível ad nutum pelo Presidente, poderia propor representações de constitucionalidade. Além disso, para além das semelhanças formais entre a Ação Direta de Constitucionalidade de 1988 e a Representação de Inconstitucionalidade criada pela Emenda n.16/65, a nova Constituição expandiu e reinventou quase que completamente os mecanismos de controle abstrato. No regime anterior, ainda que decisões de constitucionalidade em abstrato já pudessem ser um corpo político estranho na identidade profissional da instituição, seu alcance era muito restrito.

Com o texto constitucional de 1988, o poder "híbrido" do controle abstrato de constitucionalidade - judicial, mas político - é deslocado para o centro da atividade do STF. A maioria dos Ministros que integravam o STF durante a elaboração da Constituição e nos primeiros anos após sua promulgação tinha diante de si um conjunto de poderes novos, potencializados por uma abertura política e substancialmente diferentes dos limitados mecanismos de controle abstrato com os quais estavam acos-

43 Para uma discussão sobre sinceridade/estratégia no comportamento judicial, ver Arguelhes \& Ribeiro, 2012. tumados. ${ }^{44}$ Esse problema havia sido notado na comunidade jurídica alguns anos após as decisões auto-restritivas nos casos aqui citados, bem como, por exemplo, posição adotada pelo tribunal quanto ao instituto do Mandado de Injunção ${ }^{45}$. De fato, pouco mais de uma década após a

44 A percepção de que os novos poderes e as novas expectativas depositadas no STF durante a democratização eram radicalmente diferentes das funções tradicionais da instituição foi veiculada no âmbito da própria Assembleia Constituinte, em especial durante as discussões sobre a transformação do Supremo Tribunal Federal em uma Corte Constitucional em sentido mais estrito. Nesse sentido, por exemplo, o Constituinte Plínio de Arruda Sampaio asseverou: "[N]ão implantaremos uma Constituição que gere direitos novos e limite direitos antigos, se não mudarmos fundamentalmente a estrutura do Supremo Tribunal Federal. Do contrário, acontecerá com a nova Constituição o que aconteceu com a [Constituição] de 46: seus mais belos propósitos ficaram no papel, porque não houve uma ação jurisdicional nem um tribunal para exigir dos Poderes a prática daquilo que a Constituição ordenava." (Assembleia Nacional Constituinte, Atas da Comissão de Organização dos Poderes, p.94). O jurista José Lamartine Corrêa de Oliveira, por sua vez, ao ser ouvido pela Subcomissão de Poder Judiciário e Ministério Público em 27 de abril de 1987, observou: "Queiramos ou não os Ministros do atual Supremo Tribunal Federal, até por estatística, (...) aquilo que eles fazem em noventa por cento do tempo é julgar recursos extraordinários, que só raramente ocupam matéria constitucional. Quer dizer, os Ministros do Supremo Tribunal Federal, por hábito, são homens que julgam litígios que quase sempre envolvem uniformização de jurisprudência ou violação de lei federal. É com isto que eles estão acostumados. Sua sensibilidade profissional está voltada para o julgamento das questões ordinárias. Por isso não entendo, com a devida vênia, que o coração do Supremo Tribunal seja o de guarda da Constituição. Teoricamente é da Constituição, mas na realidade não, porque o Supremo funciona quase sempre como um Tribunal uniformizador de jurisprudência e como um Tribunal julgador da violação de leis federais" (Assembleia Nacional Constituinte, Atas da Subcomissão do Poder Judiciário e do Ministério Público, p.116).

45 O mandado de injunção (art. $5^{\circ}$, LXXI da Contituição) foi criado e inserido na Constituição de 1988 como um instrumento de combate ao problema das omissões constitucionais - isto é, para evitar que direitos e garantias previstos no texto constitucional nunca saíssem do papel por falta de norma regulamentadora. Contudo, no leading case MI 107, decidido em 23.11.1989 e relatado pelo Ministro Moreira Alves, o Supremo Tribunal Federal adotou uma interpretação que "esvaziou as potencialidades do novo remédio" criado pela Constituição, "rejeitando o ônus político de uma competência política que não desejava" (Barroso, 2006, p.125). Nos anos subsequentes, a jurisprudência do STF sobre o Mandado de Injunção - que foi atenuada ao longo do tempo, mas só veio a ser flexibilizada de forma significativa na segunda métade da última década - se tornou, para a comunidade jurídica, uma espécie de símbolo das reservas com que boa parte dos Ministros do tribunal viam diversas inovações institucionais da Constituição de 1988. 
promulgação da Constituição, Barroso observou:

“O constituinte de 1988 tomou, sem maior debate político, a decisão grave de manter como integrantes do STF todos os Ministros que haviam sido investidos no Tribunal pelos governos anteriores. Vale dizer: sem embargo da inegável virtude pessoal e intelectual de muitos dos juízes que lá tinham assento, a corte constitucional brasileira, encarregada de interpretar a nova Carta, era composta de juristas cuja nomeação era lançada a crédito do regime militar. Sem dever o seu título de investidura à nova ordem, e sem compromisso político com a transformação institucional que se operara no País, a Corte reeditou burocraticamente parte da jurisprudência anterior, bem como alimentou inequívoca má-vontade para com algumas inovações." ${ }^{36}$

De um lado, portanto, temos um texto constitucional novo e ambicioso, que expande os poderes do STF e amplifica os efeitos e a acessibilidade de suas decisões, sobretudo por meio da transformação da limitada Representação de Inconstitucionalidade na expansiva Ação Direta de Inconstitucionalidade. De outro, esse texto e os poderes nele previstos devem ser interpretados por Ministros cujas carreiras transcorreram em um horizonte muito diferente e muito mais limitado de jurisdição constitucional e de participação judicial na política. Nesse cenário, é possível que crenças sinceras dos Ministros sobre a função judicial - concepções tradicionais sobre função do STF, ainda presentes na composição herdada do regime militar - ajudem a explicar a tomada de decisões limitadoras do controle abstrato de constitucionalidade. ${ }^{47}$

46 Barroso, 2001, p.24

47 Alguns Constituintes estavam atentos para os riscos decorrentes desse cenário. Confira-se, por exemplo, duas das muitas manifestações de Plínio de Arruda Sampaio sobre o tema, separadas por quase um ano de debates na ANC: "A nova Constituição criará direitos novos, que não estão em nossos registros mentais, nem em nosso aparelho de Justiça. Em casa de quem não fuma, dificilmente se encontram cinzeiros porque isto não está em seu registro mental. Quem toma café sem açúcar, em geral não tem açucareiro, porque isto não está em seu registro mental. Uma Justiça que tem de julgar agora direitos novos a uma Justiça que precise de estimulo, precisa de uma chamada e precise estar atenta a esse fato." (Atas da Subcomissão do Poder Judiciário e do Ministério Público, 13 de maio de 1987, p.162); "Se o Supremo não for modificado, as outras modificações introduzidas no texto terão efeitos muito pequenos. (...) Se as questões constitucionais não tiverem peso, é inútil o trabalho que estamos aqui pela reforma agrária, pela reforma urbana, pela reforma da saúde porque isto vai continuar sendo letra morta no papel. (...) Só os tribunais é que irão fazer valer os direitos que V. Exas. estão concedendo ao

\subsection{Estratégias judiciais: os casos certos, na quan- tidade certa, no momento certo}

Outras hipóteses que podem ser levantadas para explicar as atitudes restritivas diante do controle abstrato são de caráter marcadamente estratégico. Aumentar seu poder é apenas um de muitos objetivos em pauta no processo de construção institucional de uma corte suprema em períodos de consolidação democrática. É preciso ter em mente que juízes e tribunais operam em um ambiente de interações estratégicas, no qual é esperado que suas decisões deflagrem certos comportamentos dos outros atores políticos relevantes. ${ }^{48} \mathrm{Em}$ cenários de democratização recente, em que as regras do jogo ainda não são completamente claras (nem é completamento claro se elas serão respeitadas), faz sentido para um tribunal ser cauteloso em relação a onde ou em quem vai pisar, ainda que o ideal dos Ministros seja o de exercer cada vez mais poder. ${ }^{49}$ Decidir questões políticas é uma atividade cujos riscos variam muito dependendo do contexto político. Ser forçado a se pronunciar sobre uma decisão política importante para o governo da vez é uma coisa com instituições políticas e econômicas estáveis e com mais de duas décadas desde o fim regime militar. Era, porém, algo completamente diferente e muito mais arriscado nos primeiros anos após a promulgação da Constituição de $1988 .^{50}$

povo. Mas não esse Supremo Tribunal Federal que está aí, porque esse está já esclerosado na sua estrutura traditional, que não é conveniente para um Brasil novo. (...) O Ministro do Supremo, com a nova competência que terá o Supremo, vai decidir questões muito mais ligadas à política, ao poder, à realidade sociológica, razão pela qual precisa ser um juiz mais sintonizado com o contexto econômico, sociológico, político e cultural da Nação." (Discurso perante o Plenário da ANC, 07 de abril de 1988. Diário da Assembléia Nacional Constituinte, p.9067).

48 Epstein \& Knight, 2000; Ginsburg, 2003, capítulo IV.

49 Ginsburg, 2003, pp.70-77. O exemplo mais famoso de um tribunal que, ao usar seu poder de forma cada vez mais expansiva, provocou retaliação da esfera política foi o conflito entre o Tribunal Constitucional Russo e o Presidente Boris Yeltsin. Insatisfeito com os esforços do Tribunal de atuar como árbitro entre a Presidência e o Parlamento na crise política de 1993, Yeltsin decretou o fechamento da corte em 7 de outubro de 1993. Lee Epstein, Jack Knight e Olga Shvetsova (2001) apontam que, após sua reabertura em 1995, o Tribunal Constitutional Russo adotou um comportamento muito mais cauteloso, sobretudo em relação ao tipo de casos que incluía em sua agenda.

50 Isto não equivale a dizer que o STF fugiu de toda e qualquer decisão politica difícil. Por exemplo, o tribunal assumiu a responsabilidade de rever, em 1992, no Mandado 
As duas linhas jurisprudenciais restritivas descritas nesta seção se adequam a esse tipo de intepretação estratégica, já que, como discutido acima, representaram não uma restrição completa, mas uma canalização de certas demandas e questões políticas para o controle incidental e concreto, com o consequente adiamento dessas decisões. No geral, o exercício de controle de constitucionalidade de forma abstrata expõe mais o tribunal. No controle concentrado e abstrato, tribunais correm o risco de serem catapultados para o centro de uma polêmica política dias logo após o Executivo e/ou o Legislativo terem se pronunciado sobre a questão. Não há um caso concreto a ser resolvido, apenas um juízo direto sobre a constitucionalidade de uma decisão tomada no âmbito dos outros poderes. ${ }^{51}$

Especificamente no caso do STF, mesmo quando se trata de decisões de grande impacto político, o controle incidental e difuso é mais seguro, em pelo menos dois níveis. Primeiro, o tempo processual pode ser mais facilmente maleável pelo STF nesses casos. A multiplicidade de casos e partes chegando ao STF em momentos distintos e de partes diferentes do país torna mais difícil para a mídia e a opinião pública encontrarem um ponto focal em torno do qual concentrarem seu acompanhamento e críticas. Segundo, em controle difuso e incidental, o STF pode empregar elementos do caso concreto para dar um alcance mais restrito à decisão, ou para enfatizar questões processuais em detrimento do mérito constitutional do conflito, evitando assim se envolver em polêmicas consti-

de Segurança $\mathrm{n}^{\circ}$ 21.564, o mérito de decisões da Mesa da Câmara dos Deputados relativas ao procedimento de impeachment do então Presidente Fernando Collor de Mello. Era uma questão de política de grande impacto na vida do país - e, mesmo assim, uma maioria de Ministros do STF rejeitou o argumento, mencionado em votos vencidos e comum na jurisprudência de vários países, de que o processo de impeachment era exclusivamente político e, portanto, insuscetível de apreciação judicial. Devo a Daniel Sarmento essa observação. Mesmo assim, é importante destacar que, no caso do impeachment, o STF estava diante de um processo com características mais tipicamente judiciais. Tratava-se de aplicar o princípio do devido processo legal a um caso concreto e decidir se os prazos e meios de defesa à disposição do Presidente eram ou não compatíveis com a exigência constitucional. Assim, apesar de seu grande impacto político, é possível considerar que a estrutura desse problema era mais semelhante ao que os Ministros do STF estavam acostumados a fazer, na época, do que as discussões praticamente legislativas do controle abstrato de constitucionalidade.

51 Stone, 1992; Ferreres Comella, 2009. tucionais em momentos inoportunos. ${ }^{52}$

Nesse sentido, é interessante notar que algumas das mais importantes decisões recentes do tribunal foram tomadas em sede de Arguição de Descumprimento de Preceito Fundamental (ADPF). Regulamentada apenas em 1998, a ADPF finalmente permitiu que questões envolvendo a constitucionalidade de legislação pré-constitucional pudessem ser levadas ao STF em sede de controle abstrato e com decisões de efeitos erga omnes. ${ }^{53}$ Isso permite levantar a hipótese de que, em certo sentido, com a decisão da ADI n.02, o STF ganhou tempo: garantiu que não precisaria enfrentar, logo nos anos subsequentes a 1988, ADIs versando sobre a legislação pré-constitucional, incluindo leis aprovadas pelo regime militar. No mínimo até a promulgação da Lei 9.882/99, que regulamentou a ADPF, o STF parece ter se protegido do risco de ser forçado a dar decisões de grande alcance sobre legislação aprovada antes da redemocratização.

Uma segunda explicação estratégica diz respeito ao receio, por parte dos Ministros do STF, de que a ampliação do controle abstrato produziria uma corrida imediata e em massa da sociedade civil e partidos políticos ao tribunal. Um tribunal sobrecarregado de trabalho pode acabar desperdiçando seu tempo - e, com ele, seu poder - em questões menos importantes, e faz sentido pensar que, com todas as expectativas em torno da Constituição nova e do novo sistema de controle de constitucionalidade, os Ministros do STF teriam razões para se preocupar com uma possível explosão de ADIs logo após a transição. Essa parece ser uma das justificativas reconhecidas pela doutrina constitucional brasileira para as decisões restritivas do STF quanto ao controle abstrato (BARROSO, 2006, p.148). ${ }^{54}$

52 O recurso sistemático a elementos fáticos do caso concreto ou da tramitação processual específica que levou aquela questão ao tribunal é justamente o coração da técnica decisória batizada por Cass Sunstein de "minimalismo judicial". Juízes "minimalistas" procurariam resolver um caso recorrendo a seus elementos mais específicos e sem invocar teorias com grande grau de abstração, procurando assim preservar sua capacidade de decidir livremente casos futuros. Ver Sunstein, 1999.

53 Ver, por exemplo, a decisão do STF, tomada por maioria, no sentido de que a Lei (Lei de Imprensa) não teria sido recepcionada pela a Constituição Federal de 1988 (ADPF n.130, julgada no dia 30 de abril de 2009).

54 Essa foi a explicação apresentada, em entrevista ao autor, pelo Ministro José Carlos Moreira Alves, que integrava o STF na época das decisões discutidas na seção anterior. A 
Algumas (ou todas) dessas considerações estratégicas podem ter passado pela cabeça dos Ministros na tomada das decisões discutidas acima. Além disso, as duas explicações estratégicas não são incompatíveis uma com a outra, nem excluem a pertinência da explicação das crenças sinceras levantada na seção anterior. Ao contrário, as três podem se reforçar mutuamente. Determinar o peso e o papel exato de cada um desses fatores sociológicos e estratégicos na explicação do comportamento o STF está além dos objetivos deste trabalho, mas a análise feita na seção anterior é suficiente para enfatizar dois pontos importantes.

Primeiro, a explicação "oficial” - de que o objetivo dos Ministros teria sido evitar uma explosão de litigiosidade capaz de ameaçar o papel do STF como defensor da Constituição - é pouco persuasiva. Quanto ao objeto das ADIs, se havia de fato uma demanda reprimida pelo afastamento imediato e com efeito erga omnes de leis do regime anterior, é provável é que ela envolvesse um conjunto limitado, ainda que numeroso, de leis particulamente controvertidas, como a Lei de Imprensa. É improvável que a possibilidade de se questionar legislação pré-constitucional por meio de ADI levasse ao ajuizamento de milhares de novas ações. ${ }^{55}$ Quanto ao acesso ao controle concentrado, a explicação parece um pouco mais plausível. Entretanto, é difícil compatibilizá-la com as posições dos próprios Ministros do STF, antes e durante a Assembléia Constituinte, em sentido contrário a

preocupação com a sobrecarga de trabalho no STF já havia sido expressa pelo Ministro ainda nos anos 80 (Moreira Alves, 1982), vindo a ser expressamente renovada na época da promulgação da Constituição. Em texto contemporâneo à Assembléia Constituinte de 87-88, Moreira Alves afirmou que a expansão exagerada do acesso ao controle concentrado de constitucionalidade contribuiria para uma crise - de volume de trabalho e de credibilidade - do Supremo Tribunal Federal (Moreira Alves, 1988).

55 Com dados do $1^{\circ}$ Relatório "Supremo em Números" (Falcão, Cerdeira e Arguelhes, 2011, p.37), é possível questionar se é verdade que, na ausência de restrições a quem pode ajuizar ADIn, como a da "pertinência temática", a carga de trabalho do STF teria subido de forma incontrolável. As ações classificadas pelo relatório como primariamente "constitucionais" (categoria que, em 1988, incluiria apenas ADIns e Mandados de Injunção - MIs) representaram cerca de $1 \%$ da carga total de processos do tribunal em 1988, cerca de 3\% em 1989 e menos de 2\% em 1990. Ou seja, mesmo em 1988-89, antes da "jurisprudência restritiva" quanto à legitimidade ativa do STF se consolidar, ADIns e MIs jamais passaram de $3 \%$ do volume de processos do tribunal. reduções nas competências recursais do tribunal. De fato, na já citada mensagem à Comissão Afonso Arinos, o STF havia se manifestado contra tanto a sua transformação em um Tribunal Constitucional exclusivo, quanto à criação do Superior Tribunal de Justiça para uniformizar a aplicação da legislação federal (e, com isso, diminuir o volume de trabalho do STF). Mesmo que a preocupação com a explosão de litigiosidade tenha de fato sido uma das razões por trás da jurisprudência restritiva, é preciso explicar por que ela se traduziu primariamente em uma aversão ao controle abstrato e concentrado, e não às outras competências do tribunal, que são mais significativas em termos do número de casos que atraem. ${ }^{56}$ Isso sugere que, para o STF do período pós-Constituinte, o problema não era apenas controlar a quantidade de casos, mas também o tipo de casos, o momento certo para julgá-los e o tipo de poder empregado na sua resolução - o que só reforça a importância das outras hipóteses levantadas nesta seção.

Segundo, seja qual for a combinação de preocupações estratégicas e crenças sinceras que formataram a percepção de um ou outro Ministro específico naqueles processos decisórios, o fato é que o resultado final agregado dos votos expressou uma restrição relativa e delibera-

56 Em 1990, ano em que começou a se consolidar a jurisprudência restritiva do STF quanto à legitimação para propositura de ADIn, os Agravos de Instrumento e Recursos Extraordinários representavam $80 \%$ dos processos recebidos pelo Tribunal. De 1991 em diante, esse número se mantém acima de $90 \%$ até 2007 (os dados são do Portal de Informações Gerenciais do STF e estão disponíveis em: http:// www.stf.jus.br/portal/cms/verTexto.asp?servico=estatistica\&pagina=REAIProcessoDistribuido). Isto sugerr que, ainda que as restrições ao ajuizamento de ADIns sejam consideradas as principais responsáveis por essa diferença após 1991, os instrumentos processuais ligados ao controle difuso de constitucionalidade (Recursos Extraordinários e Agravos de Instrumento) já respondiam sozinhos por 4/5 da carga de trabalho do STF antes mesmo das restrições no acesso às ADIns serem aplicadas de forma sistemática. Mais ainda, o percentual restante de casos novos não corresponde apenas a ADIns e outros processos de controle concentrado e abstrato de constitucionalidade, incluindo processos em que se realiza controle concreto, como Habeas Corpus e Mandados de Segurança. Nesse cenário, mesmo em 1990, as competências do STF relativas ao controle concentrado de constitucionalidade dificilmente poderiam ser consideradas o grande front na briga do tribunal contra a sobrecarga de processos. É interessante notar que o próprio Ministro Moreira Alves havia reconhecido, em texto publicado durante a constituinte, que a chamada "crise do Supremo Tribunal Federal" era, em última instância, "a crise do recurso extraordinário” (Moreira Alves, 1988:35). 
da dos poderes do STF. Trata-se de um claro exemplo de como a previsão textual de poderes de controle de constitucionalidade e de demanda de atores sociais e políticos por intervenção judicial no processo político não são fatores suficientes para determinar o grau de participação de um tribunal na vida política do país em um dado momento.

\section{Preferências judiciais restritivas e 'judiciali- zação da política'}

Nas seções anteriores, procurou-se defender o argumento de que os membros do Supremo Tribunal Federal não necessariamente querem exercer o máximo de poder possível. Mais ainda, a análise de parte da jurisprudência restritiva do STF no início dos anos 90 indicou que essas preferências por uma atuação restrita na esfera política podem se converter (e, no Brasil pós-constituição, de fato se converteram) em transformações duradouras no desenho institucional. Neste ponto, surge uma possível conexão com a vasta e crescente literatura sobre "judicialização da política” do Brasil. Como observado na seção I deste trabalho, essa literatura tende a explicar o fenômeno "judicialização" a partir de variáveis exógenas à composição e às próprias decisões do Supremo. Entretanto, se reconhecemos que Ministros pouco dispostos a exercer poderes textualmente previstos podem reconfigurar o próprio desenho da instituição de acordo com suas preferências restritivas, cabe investigar se e como essas variáveis não-exógenas podem ser úteis para se compreender o timing e o grau das transformações no poder do STF dos anos 90 para cá. Nesse sentido, o objetivo desta seção é sistematizar conceitualmente os resultados da análise feita nas seções anteriores, utilizando o quadro teórico do debate sobre "judicialização da política".

O papel das preferências judiciais no sentido de viabilizar ou não a judicialização da política já havia sido explicitamente discutido e reconhecido no artigo de Tate, publicado em 1995, que se tornou uma das referências principais no debate sobre judicialização dos anos 90 para cá. Naquele trabalho, a "judicialização da política" foi definida como um processo duplo: de um lado, o processo pelo qual tribunais participam cada vez mais da elaboração de políticas públicas que, anteriormente, eram elaboradas (ou deveriam ser elaboradas, segundo a concepção dominante) por outras instituições do governo; de outro, (b) o processo pelo qual fóruns decisórios não-judiciais passam a ser dominados por regras e procedimentos quase-judiciais. No que se refere ao processo político decisório nacional, este segundo eixo da judicialização não parece ter sido sistematicamente explorado no debate brasileiro até o momento. Para os fins deste trabalho, enfocaremos "judicialização da política" a partir do primeiro eixo descrito por Tate, que parece refletir um denominador comum mínimo entre grande parte dos estudos sobre o papel do STF na política nacional. Nessa matriz teórica, explicar o processo de judicialização da política no Brasil significa perguntar, no caso do Supremo, quais variáveis explicam a expansão da esfera de atuação do tribunal, que, cada vez mais, participa da decisão dequestões tradicionalmente restritas a outras instituições governamentais.

Tate enumera oito condições "facilitadoras" desse tipo de processo: (i) a existência de um regime democrático; (ii) a separação de poderes; (iii) a existência de direitos políticos garantidos a minorias; o uso dos tribunais por parte de (iv) grupos de interesse e (v) pela oposição; (vi) partidos políticos e governos de coalizão fracos que, ao produzirem políticas inefetivas e com pouco apoio, aumentam a ação da oposição no judiciário - condição que os autores denominam de "instituições majoritárias inefetivas"; (vii) percepção pública negativa das instituições majoritárias; e, por fim, (viii) a delegação para os tribunais de medidas e decisões que as instituições majoritárias não considerem oportuno tomar. Segundo Tate, essas condições são importantes, mas insuficientes para gerar judicialização - daí a afirmação do seu caráter meramente "facilitador". Não são necessárias, nem suficientes para que se gere um estado de coisas em que ocorre o fenômeno da judicialização.

Contudo, se todas as oito condições se verificarem em um dado cenário, o que faltaria para o judiciário participar de forma significativa do processo político decisório? No modelo explicativo de Tate, isso só ocorre caso os juízes entendam que devem participar do processo decisório realizado por outras instituições e interferir nas soluções de políticas públicas formuladas desse processo. Embora ciente de que mesmo uma "não decisão" de alguma forma implica tomar uma decisão, o fenômeno da judicialização na formulação de Tate possui um componente ativo ou positivo por parte dos juízes na tomada de decisão. Para fins da ocorrência de judicialização da política, não basta que os casos sejam levados ao judiciá- 
rio. A judicialização requer que os juízes tenham atitudes, predisposições pessoais ou valores que os levem a procurar participar do processo decisório. Na terminologia do autor, a judicialização pressupõe uma orientação dos juízes para o "ativismo judicial" (preferência por participar do processo político decisório), em contraposição à orientação de "auto-contenção judicial" ${ }^{57}$

Podemos dizer que tanto "ativismo", quanto "auto-contenção" operam como preferências de segunda ordem: elas orientam a forma pela qual o juiz, diante uma policy cuja constitucionalidade está em discussão, levará em conta suas preferências de primeira ordem acerca daquela policy. ${ }^{58}$ Nesse sentido, são preferências que podemos chamar de formais ou funcionais: não dizem respeito ao mérito da questão política submetida à apreciação judicial, mas orientam o juiz a levar ou não em conta suas preferências substanciais por políticas públicas específicas na tomada de decisões em controle de constitucionalidade. Esses pontos podem ser ilustrados de forma esquemática no quadro abaixo:

\begin{tabular}{|c|c|c|}
\hline \multirow[b]{2}{*}{$\begin{array}{c}\text { Preferências } \\
\text { substanciais (ou de } \\
\text { primeira ordem) }\end{array}$} & \multicolumn{2}{|c|}{ Preferências funcionais (ou de segunda ordem) } \\
\hline & $\begin{array}{l}\text { Juízes estão dispostos } \\
\text { participar da tomada de } \\
\text { decisões políticas }\end{array}$ & $\begin{array}{c}\text { Juízes não estão dispostos } \\
\text { a participar da tomada de } \\
\text { decisões políticas }\end{array}$ \\
\hline $\begin{array}{c}\text { Juízes discordam das } \\
\text { decisões políticas sendo } \\
\text { tomadas }\end{array}$ & $\begin{array}{c}\text { (1) Judicialização } \\
\text { plena }\end{array}$ & $\begin{array}{l}\text { (2) Judicialização } \\
\text { limitada }\end{array}$ \\
\hline $\begin{array}{c}\text { Juízes concordam com as } \\
\text { decisões políticas sendo } \\
\text { tomadas }\end{array}$ & $\begin{array}{l}\text { (3) Judicialização } \\
\text { limitada }\end{array}$ & $\begin{array}{l}\text { (4) Judicialização } \\
\text { limitada }\end{array}$ \\
\hline
\end{tabular}

Assim, no sentido dado por Tate, a judicialização é

57 Tate, 1995, p.33-34.

58 Se essas preferências resultarem de uma tomada de posição consciente por parte do juiz, uma possível maneira de formalizá-las em termos de teoria da argumentação jurídica seria equipará-las às decisões de segunda ordem analisadas por Sunstein \& Ullmann-Margalit (1999), no sentido de que são decisões tomadas ex ante sobre como decidir casos futuros. Outra possibilidade seria considerá-las como razões substancialmente mais fortes do que as razões ligadas ao mérito do caso. Agradeço a Fernando Leal por me esclarecer essas questões. Para os fins deste trabalho, o importante é reconhecer que há em jogo razões mais complexas do que a simples preferência substancial do juiz, independentemente da forma específica pela qual elas interagem com as preferências substanciais. Sobre escolhas entre concepções normativas da decisão judicial como decisões de segunda ordem, ver Arguelhes \& Leal, 2009. um fenômeno que só ocorre de forma plena quando (i) as condições facilitadoras existem, (ii) os valores dos juízes não são coincidentes com os valores da coalizão majoritária, refletidos na legislação aprovada na arena política legislativa e (iii) os juízes estão dispostos a participar da tomada de decisões políticas. É a situação descrita no quadrante (1), acima. ${ }^{59}$ Segundo o argumento do autor, caso os valores sejam compartilhados entre os juízes e as instituições majoritárias, os incentivos para que os juízes procurem participar do processo decisório são baixos (situação descrita nos quadrantes (3) e (4)). ${ }^{60}$ Vale insistir que o que torna relevantes, na prática, as preferências substanciais dos juízes para a ocorrência ou não de judicialização plena é a condição prévia relativa às preferências funcionais desses mesmos magistrados. Afinal, um juiz que não tenha preferências funcionais "ativistas", no sentido de Tate, resistirá a participar de decisões de políticas públicas ainda que suas preferências substanciais estejam em desacordo com a legislação adotada pela coalizão majoritária (situação descrita no quadrante (2), acima)).

A própria formulação do conceito de judicialização que se tornou referência nos estudos sobre o tema, portanto, já chamava a atenção para a complexa interação entre valores dos atores relevantes, relações e interações

59 Vale notar que a judicialização é aqui classificada como "plena" ou "limitada" em termos relativos, isto é, em comparação com o nível de judicialização encontrado nos outros quadrantes. A judicialização no quadrante (1) é plena em comparação com o que ocorre nos outros três quadrantes, que são mais próximos entre si do que desse nível de judicialização. Isso não exclui, porém, a possibilidade de os estados de coisas observáveis nos quadrantes 2,3 e 4 serem significamente diferentes entre si em vários níveis. Por exemplo, no quadrante 3, é possível que um tribunal com preferências "ativistas" decida manter uma dada policy - e, portanto, agradar a coalizão majoritária da vez - ao mesmo tempo que faz isso por razões diferentes das fornecidas na aprovação da política pública na arena majoritária. Aqui, o tribunal pode usar a motivação da decisão para expandir seu poder. O exemplo clássico desse tipo de estratégia na construção de poder por parte de instituições judiciais foi o caso Marbury v. Madison, decidido em 1803 pela Suprema Corte dos EUA (ver nota 14, supra).

60 Essa proposição de Tate parece questionável, tendo em vista que juízes podem ter preferências orientadas a aumentar sua influência na política mesmo que não alterem $o$ conteúdo das decisões tomadas pelos outros dois poderes. Assim, dentro de um mesmo Tribunal, dois juízes que têm preferências políticas opostas sobre uma dada questão podem ainda assim convergir em torno da necessidade de o Tribunal se manifestar sobre o caso de forma a ampliar o seu espaço no processo decisório democrático (Ginsburg, 2003, p.75-76). 
entre instituições e condições objetivas restritivas da ação política. O conceito de judicialização de Tate incorporava uma variável relativa às preferências individuais dos membros de tribunais constitucionais e cortes supremas, mostrando que uma preferência por restrição pode limitar ou bloquear a influência de todas as outras condições facilitadoras da judicialização da política. Esse ponto, primariamente conceitual, pode ser útil para discutir e explicar com mais precisão graus diferentes, ao longo do tempo, de participação do tribunal na vida política do país.

A incorporação de variáveis ligadas às preferências funcionais dos Ministros pode contribuir para nossa compreensão do timing da judicialização da política no Brasil. O comportamento do STF em relação a aspectos centrais do controle de constitucionalidade após a promulgação da Constituição de 1988 é um eloquente lembrete de que poder não é necessariamente querer. Em sentidos importantes, decisões tomadas no âmbito do Supremo diminuíram o poder do tribunal em relação ao que havia sido textualmente previsto na Constituição. Podiam, mas não quiseram. Reconhecer a diferença e a possível interação entre "poder" e "querer" na relação entre o STF e a política tem implicações importantes em pelo menos dois níveis. O primeiro é pontual: em determinados casos, os Ministros podem não querer usar um poder que, por força do texto constitucional e/ou das expectativas dos outros atores políticos, já está alguma medida à sua disposição. Essa possível divergência entre o poder e o querer em casos específicos, levando variações no grau de agressividade com que os Ministros usam seus poderes, é reconhecido na comunidade jurídica. ${ }^{61}$ Não há dúvida de que ter poder não significa necessariamente usar esse poder em todo e qualquer caso. Neste trabalho, porém, procurei chamar a atenção para um fato diferente: a própria extensão do poder institucional do STF é também influenciada pelas preferências funcionais dos Ministros que o compõem em um dado momento. Nesse segundo sentido, um tipo de poder indesejado ou inconveniente não apenas não é exercido, como pode ser reconstruído e até eliminado da própria estrutura constitucional que originalmente o consagrava.

É nesse segundo sentido que tematizar a relação entre poder e querer pode ser relevante para os debates

61 Barroso, 2010, p.08-10. sobre judicialização da política no Brasil. O desenho institucional é tipicamente considerado uma variável exógena à vontade do STF que afeta o grau observado de judicialização, mas, muitas vezes, é o querer dos Ministros que configura o próprio desenho institucional. ${ }^{62}$ Quando Ministros do STF não desejam exercer poder, ou preferem exercê-lo de outras formas, têm excelentes condições de transformar o desenho institucional existente de modo a aproximá-lo do seu arranjo preferido. Dependendo do contexto, essa restrição pode se extender muito além do caso concreto e institucionalizar um grau limitado de participação do tribunal na política, ainda que as variáveis exógenas discutidas na literatura (como o desenho institucional e o comportamento dos atores políticos apontem na direção de uma expansão do poder do tribunal.

A influência, sobre decisões do STF, de atitudes e concepções dos Ministros em relação ao seu papel institucional já vem sendo documentada. Por exemplo, há estudos sugerindo que certos Ministros exibem padrões decisórios que podem ser correlacionados com concepções individuais mais ou menos "expansivas" ou "restritivas" sobre o papel do tribunal. ${ }^{63}$ Assim, em alguma medida, variações nos perfis dos Ministros podem afetar o conteúdo das decisões do Tribunal. Entretanto, esse tipo de variável ainda não foi sistematicamente integrado no debate nacional mais amplo sobre judicialização da política, que tende a enfocar o efeito de variáveis externas ao comportamento dos membros do tribunal. ${ }^{64}$

Parece haver uma espécie de "divisão de trabalho" entre as variáveis: perfis, preferências e atitudes dos $\mathrm{Mi}$ nistros tendem a ser incorporadas na análise do resultado de decisões do STF, mas não na explicação das grandes transformações no poder do tribunal de 1988 para cá. Essa divisão é problemática quando reconhecemos que o efeito das preferências judicias sobre desenho institucional não se dá apenas no resultado de casos específicos - isto é, não se restringe a variações no uso de um

62 Barroso observa que, quando se trata de exercício de poder judicial "o que se quer é balizado pelo que se pode e pelo que se deve fazer" (2010, p.05). Nessa imagem, o querer é limitado pelo desenho institucional. Quero apontar para a possibilidade oposta: no longo prazo, o que se pode fazer é balizado, por meio da interpretação constitucional, pelo que se quer fazer.

63 Oliveira, 2008.

64 Ribeiro et al, 2009. 
poder institucional que, em sua estrutura, permaneceria estável ao longo do tempo. O caso do Brasil pós-constituinte sugere que o efeito observável dos fatores exógenos a um dado tribunal pode ser modulado, tanto para mais, quanto para menos, por preferências e atitudes dos seus membros quanto ao desenho dos poderes de que dispõem. Em certas condições, uma maioria de Ministros com preferências restritivas tem recursos e incentivos para efetivamente transformar o próprio desenho institucional existente.

\section{Conclusão}

$\mathrm{O}$ argumento mais amplo avançado neste trabalho é o de que as transformações no grau de participação do STF na política brasileira não podem ser plenamente explicadas apenas com recurso a fatos sobre o contexto político e institucional externo ao tribunal. O processo de expansão ou retração do poder judicial é resultado da combinação de fatos político-institucionais e atitudes judiciais - mais especificamente, das preferências majoritárias, em uma dada composição do tribunal, sobre quais são as formas adequadas e/ou oportunas de se pronunciar sobre questões políticas. Conectando esse argumento com a matriz teórica proposta por Tate (1995), chamaram-se essas concepções de "preferências funcionais". Não se referem à substância ou mérito de casos específicos, mas sim à natureza e o alcance das competências do STF. São preferências judiciais sobre como participar da política. Dado um poder inicial mínimo de interpretar a constituição, ainda que o desenho institucional, o texto constitucional, as demandas sociais e o comportamento estratégico dos outros atores políticos apontem no sentido de uma grande participação judicial, o efeito combinado desses fatores exógenos “judicializantes” será modulado pelas preferências funcionais dominantes na composição do tribunal. Se as preferências funcionais majoritárias forem restritivas, o poder de interpretar a constituição possivelmente será usado para mover o desenho institucional em direções nas quais o tribunal participará menos intensamente da vida política do país.

A plausibilidade dessa hipótese e o poder explicativo das variáveis ligadas às preferências funcionais observáveis dos Ministros foram sustentados por meio de uma breve análise dos primeiros anos do processo de expansão do poder de Supremo Tribunal Federal iniciado com a promulgação da Constituição de 1988. Em diversas decisões no início dos anos 90, uma maioria de Ministros do STF procurou estabelecer restrições relativas ao seu próprio poder. Os esforços de interpretação constitucional discutidos neste artigo podem ser considerados como restrições, pois diminuíram o escopo da agenda do tribunal em sede de controle abstrato e concentrado de constitucionalidade. Por outro lado, são restrições relativas, porque (a) podiam ser revertidas pelo tribunal a qualquer momento e com baixo custo (já que eram resultado de interpretação constitucional, não de alteração formal do texto) e (b) deixavam abertas as portas do controle de constitucionalidade por via incidental.

Esse comportamento não é necesariamente irracional, nem paradoxal. O STF não apenas manteve plena flexibilidade para rever essa jurisprudência restritiva e para apreciar essas questões políticas pela forma mais "segura" do controle incidental, como também agiu de forma compatível com o comportamento típico de instituições judiciais durante períodos de transição e consolidação política. Na verdade, essa "autorestrição provisória” é perfeitamente racional se levarmos em conta que, em períodos de democratização recente, especialmente se cumulada com problemas econômicos e/ou sociais urgentes, instituições judiciais podem ter motivos estratégicos para recusar um papel protagônico no cenário político, dada a relativa incerteza em relação ao futuro institucional do país. ${ }^{65}$ Em última instância, portanto, o que se observou foram esforços não para eliminar, mas sim para adiar parte da agenda potencial da jurisdição constitucional no Brasil.

Na narrativa apresentada neste trabalho, preferências judiciais contrárias ao exercício de poder em controle abstrato de constitucionalidade se combinaram com o poder de interpretar a constituição para gerar e estabilizar jurisprudência autorestritiva. Mas é interessante notar que, nos casos analisados, embora os fins tenham sido

65 Cf., por exemplo, Ginsburg, 2003, p.71-72, p.95. Em sentido diverso, argumentando que, em cenários de refundação política da comunidade, cortes superiores tendem a possuir recursos e incentivos para agir de forma mais agressiva perante os outros poderes, cf. Ackerman, 1997. Parece-me, porém, que a concepção de Ackerman assume preferências judiciais perfeitamente convergentes com uma maior agressividade judicial - o que não necessariamente é o caso, como o exemplo do Brasil parece mostrar - e desconsidera a possibilidade de juízes modularem, com base em considerações estratégicas, o que seria a sua decisão preferida em condições políticas mais favoráveis. 
autorestritivos (restrição do alcance do controle abstrato e concentrado de constitucionalidade), os meios empregados pela maioria dos Ministros do STF foram generosos e expansivos. O resultado das decisões teve caráter restritivo, mas essas decisões foram alcançadas por meio de interpretações relativamente livres e, em vários casos, pouco deferentes em relação ao texto constitucional aprovado pela Assembléia Constituinte. O outro lado dessa história de liberdades interpretativas é que, mudando-se as preferências judiciais em jogo, e mantendo-se as variáveis exógenas na mesma direção, criam-se condições favoráveis a mais judicialização. $\mathrm{O}$ mesmo mecanismo que reconstruiu o controle de abstrato de forma restritiva é capaz de promover mudanças expansivas na presença das condições certas - como, por exemplo, a progressiva substituição dos Ministros indicados no regime anterior por juristas socializados em uma comunidade profissional mais acostumada a ver o STF nas páginas de política dos jornais. ${ }^{66}$ Independentemente de o cenário atual ser de maior ou menor judicialização, é importante levar em conta o querer judicial expresso nas decisões e declarações dos Ministros, bem como as concepções de jurisdição que o estruturam.

Os argumentos e análises desenvolvidos neste trabalho possuem implicações que parecem merecer exploração em trabalhos empíricos sobre o STF e a política. Independemente do rótulo conceitual - "ativismo", "judicialização" - que seja utilizado para discutir a transformação do papel do STF na vida nacional, fatos político-institucionais exógenos à composição do tribunal são insuficientes. Se o poder do STF em controle abstrato foi reconstruído em direções restritivas após a transição porque uma maioria de Ministros assim o quis, como compreender a progressiva transformação da contenção de ontem no protagonismo de hoje sem levar em con-

66 Por exemplo, a crescente popularidade, na comunidade jurídica Brasileira, de teorias normativas da decisão judicial que encorajam o uso de argumentos morais e políticos na jurisdição constitucional pode ter contribuído para mover as preferências funcionais dos Ministros (e potenciais indicados ao STF) no sentido de maior participação em decisões políticas por meio de controle abstrato (cf. Leal, 2010). Sendo ou não o caso, o importante é destacar que, em última instância, mesmo as mais populares teorias normativas da decisão judicial não são impostas aos Ministros, mas sim deliberadamente escolhidas dentro de um conjunto de alternativas possíveis - o que só reforça a importância do querer judicial. ta o "querer" dos membros do tribunal? Nesse sentido, é preciso redobrada cautela com narrativas que "despersonalizem" a construção do protagonismo do STF dos anos 90 aos dias de hoje - sejam elas formuladas por acadêmicos ou articuladas nas decisões e nas frequentes manifestações públicas dos próprios Ministros. Importa saber quais são as ideias e preferências dominantes, entre os Ministros do Supremo, com relação ao papel do STF na democracia brasileira. Qualquer que seja o rótulo conceitual ou a perspectiva adotada, o fato é processos de restrição ou de expansão desse papel dependem também do que uma dada composição do tribunal deseja poder fazer.

\section{Referências}

ACKERMAN, B. 1997. The Rise of World Constitutionalism. Virginia Law Review, v. 83, $\mathrm{n}^{\circ} 4$, pp.771-97.

ALVES, P.C.A. 2009. Diga 'Trinta e Três': uma Tentativa de Diagnóstico da Agenda Política do STF e dos Órgãos de sua Burocracia Processual. In: COUTINHO, D.; VOJVODIC, A. Jurisprudência Constitucional: Como Decide o STF? São Paulo: Malheiros.

ANDRADE, L.S. 2009. Controle de Constitucionalidade das Normas Pré-Constitucionais na Jurisprudência do STF - O julgamento da ADI 02, as razões determinantes do tribunal e as consequências da postura adotada. In: COUTINHO, D.; VOJVODIC, A. Jurisprudência Constitucional: Como Decide o STF? São Paulo: Malheiros.

ARGUELHES, D.W.; LEAL, F.R. 2009. Pragmatismo como [Meta]Teoria da Decisão Judicial: Caracterização, Estratégias e Implicações. In: SARMENTO, D. Filosofia e Teoria Constitucional Contemporâneas. Rio de Janeiro: Lumen Juris.

; RIBEIRO, L.M. Pressupostos Institucionais de Teorias sobre Comportamento Judicial e o Caso Brasileiro. Trabalho apresentado no $8^{\circ}$ Encontro Anual da ABCP, 04 de agosto de 2012, Gramado (RS).

BARAK, A. 2006. The Judge in a Democracy. Princeton: Princeton University Press.

BARROSO, L.R. 2010. Judicialização da Política, Ativismo Judicial e Legitimidade Democrática. Revista Jurídica da Presidência, v. 12, nº. 96, pp. 3-41, fev/maio.

2009. Judicialização, Ativismo Judicial e Legitimidade Democrática. Atualidades Jurídicas Revista Eletrônica do Conselho Federal da OAB, n. 4, Jan/Fev. Disponível no site: http://www.oab.org.br/ oabeditora/users/revista/1235066670174218181901.pdf. 
Acesso em 15 de setembro de 2010.

2006. O Controle de Constitucionalidade das Leis no Direito Brasileiro. $2^{\text {a }}$ ed. São Paulo: Saraiva.

2001. Doze Anos da Constituição Brasileira de 1988. In: BARROSO, L.R. Temas de Direito Constitucional. Tomo I. Rio de Janeiro: Renovar.

CARVALHO, E.R. 2010. Trajetória da revisão judicial no desenho constitucional brasileiro: tutela, autonomia e judicialização. Sociologias, v. 12, n 23, pp. 176-207, jan/ abril.

2004. Em busca da judicialização da política no Brasil: apontamentos para uma nova abordagem. Revista de Sociologica e Política, v. 23, pp. 127-139. Disponível em: www.scielo.br/scielo.php?script $=$ sci_arttext\&pid=S010444782004000200011\&lng=en\&nrm=iso. Acesso em 15 de setembro de 2010 .

CASTRO, M.F. 1997. O Supremo Tribunal Federal e a Judicialização da Política. Revista Brasileira de Ciências Sociais, v. 12 , n. 34 .

EPSTEIN, L.; KNIGHT, J.; SHVETSOVA, O. 2001. The Role of Constitutional Courts in the Establishment and Maintenance of Democratic Systems of Government. Law \& Society Review, v. 45, pp. 362-377.

EPSTEIN, L.; KNIGHT, J. 2000. Toward a Strategic Revolution in Judicial Politics: A Look Back, a Look Forward. Political Research Quarterly, v. 53, pp. 625-661.

ESTADO DE SÃO PAULO. 1986. Sugestões do Supremo Tribunal Federal à Comissão Provisória de Estudos Constitucionais. Reportagem publicada em 03 de agosto de 1986.

FALCÃO, J.; LENNERTZ, M. 2008. Separação de Poderes: Harmonia ou Competição?, Revista Jurídica Consulex, v. $12, \mathrm{n}^{\circ} .281$, pp. $28-29$, setembro.

.; CERDEIRA, P.C.; ARGUELHES, D.W. $1^{\circ}$ Relatório Supremo em Números: O Múltiplo Supremo. Rio de Janeiro: FGV Direito Rio, 2011.

FOLHA DE SÃO PAULO. 1987. Para ministros do STF, mecanismos de controle devem sofrer mudanças. Reportagem publicada em 10 de julho de 1987.

FERREIRA, C. C. 2009. Os Critérios de Legitimidade Reconhecidos pelo STF para Propositura de Ação Direta de Inconstitucionalidade, In: COUTINHO, D.; VOJVODIC, A. Jurisprudência Constitucional: Como Decide o STF? São Paulo: Malheiros.

FERRERES COMELLA, V. 2009. Constitutional Courts and Democratic Values. A European Perspective. New
Haven: Yale University Press.

FISHER, L. 1988. Constitutional Dialogues: Interpretation as a Political Process. Princeton: Princeton University Press.

GINSBURG, T. 2003. Judicial Review in New Democracies: Constitutional Courts in Asian Cases. Cambridge: Cambridge University Press.

LEAL, F.R. 2010. Todos os Casos Jurídicos São Difíceis? Sobre as relações entre efetividade, estabilidade e teorias da decisão constitucional. Revista de Direito do Estado, v.16.

MENDES, G.F. 2004. Moreira Alves e o Controle de Constitucionalidade no Brasil. $2^{\text {a }}$ ed. São Paulo: Saraiva.

MOE, T.; HOWELL, W.G. 1999. The Presidential Power of Unilateral Action. Journal of Law, Economics \& Organization, v. 15, $\mathrm{n}^{\circ} 1$, pp. 132-179.

MOREIRA ALVES, J.C. 1982. A Missão Constitucional do Supremo Tribunal Federal e a Argüição de Relevância de Questão Federal. Revista do Instituto dos Advogados Brasileiros, v. XVI, no $58 / 59$.

1988. O Supremo Tribunal em Face da Nova Constituição: Questões e Perspectivas. Arquivos do Ministério da Justiça, v. 41, nº 173, julho/setembro.

. 1996. O Controle de Constitucionalidade no Brasil. Revista da Procuradoria-Geral da República, nº 9.

OLIVEIRA, F.L. 2008. Justice, professionalism, and politics in the exercise of judicial review by Brazil's Supreme Court. Brazilian Political Science Review, v. 2, $\mathrm{n}^{\circ}$ 2, pp.93-116, junho/dezembro.

. 2004. O Supremo Tribunal Federal no processo de transição democrática: uma análise de conteúdo dos jornais Folha de S. Paulo e O Estado de S. Paulo. Revista de Sociologia e Política, v. 22, pp. 101-118.

POGREBINSCHI, T.2012.Judicialiação ou Representaçao? Política, Direito e Democracia no Brasil. Rio de Janeiro: Campus/Elsevier.

RIBEIRO, L.M.; ARGUELHES, D.W.; PEIXOTO, V. 2009. Judiciário, Processo Decisório e Políticas Públicas: Levando a Decisão Judicial a Sério. Trabalho apresentado no $33^{\circ}$ Encontro Anual da ANPOCS, Caxambu (MG).

RIOS-FIGUEROA, J.; TAYLOR, M.M. 2006. Institutional Determinants of the Judicialisation of Policy in Brazil and Mexico. Journal of Latin American Studies, v. 38, pp. 739766.

STONE, A. 1992. The Birth of Judicial Politics in France: 
The Constitutional Council in Comparative Perspective. New York: Oxford University Press.

STONE SWEET, A. Constitutionalism, Rights and Judicial Power. In: CARAMANI, D. (org.). Comparative Politics. Oxford: Oxford University Press, pp. 217-239.

.2007. Juridical Coup D'État and the Problem of Authority. German Law Journal, v. 8, n 10, pp. 915-928.

2000. Governing with Judges: Constitutional Politics in Europe. Oxford: Oxford University Press.

SUNSTEIN, C. 1999. One Case at a Time: Judicial Minimalism in the U.S. Supreme Court. Cambridge: Harvard University Press.

.; ULLMAN-MARGALIT, E. 1999. Second-Order

Decisions. Ethics, v. 110, no 1, pp. 5-31.

TATE, N. 1995. Why the Expansion of Judicial Power? In: TATE, N.; VALLINDER, T. The Global Expansion of Judicial Power. New York: New York University Press.

TAYLOR, M.M. 2008. Judging Policy: Courts and
Policy Reform in Democratic Brazil. Stanford: Stanford University Press.

; DA ROS, L. 2008. Os Partidos dentro e fora do poder: a judicialização como resultado contingente da estratégia política. DADOS - Revista de Ciências Sociais, v. $51, \mathrm{n}^{\circ} 4$.

VERÍSSIMO, M.P. 2008. A Constituição de 1988, Vinte anos depois: Suprema Corte e 'ativismo judicial à brasileira'. Revista DIREITO GV, v. 4, n 2, pp. 407-440, julho/dezembro.

VIANNA, L.W.; BURGOS, M.B.; SALLES, P.M. 2007. Dezessete Anos de Judicialização da Política. Tempo Social, v. 19, no 2, pp. 39-85.

VIEIRA, O.V. 2008. Supremocracia. Revista DIREITO $G V$, v. 4, no 2 , pp. 441-464, julho/dezembro.

VOJVODIC, A.M.; MACHADO, A.M.; CARDOSO, E.L.C. 2009. Escrevendo um Romance, Primeiro Capítulo: Precedentes e Processo Decisório no STF. Revista DIREITO GV, v. 5, no 1, pp. 21-44. 